\title{
Integrative Management of Metabolic Syndrome in Youth Prescribed Second-Generation Antipsychotics
}

\author{
Jessie Rice ${ }^{1}$ and Ujjwal Ramtekkar $2,3,4, *$ (i) \\ 1 Department of Psychiatry, University of Arizona, Tucson, AZ 85721, USA \\ 2 Partners for Kids, Columbus, OH 43215, USA \\ 3 Department of Psychiatry and Behavioral Health, The Ohio State University College of Medicine, \\ Columbus, $\mathrm{OH} 43210$, USA \\ 4 Nationwide Children's Hospital, The Ohio State University College of Medicine, Columbus, OH 43210, USA \\ * Correspondence: Ujjwal.Ramtekkar@nationwidechildrens.org
}

Received: 28 April 2020; Accepted: 30 July 2020; Published: 17 August 2020

check for updates

\begin{abstract}
Weight gain and metabolic syndrome are common side effects of second-generation antipsychotics and carry significant health consequences both in childhood and into adulthood. This review highlights evidence-based, non-pharmacologic interventions to assist in the management of these side effects. Such intervention categories include dietary, physical activity, sleep, stress management, and nutritional supplementation. Interventions with the highest quality evidence include increasing the consumption of fruits, vegetables, and whole grains, increasing physical activity, improving sleep, and fish oil supplementation. We suggest that clinicians work with patients on managing metabolic side effects in a patient-centered way, incorporating principles of motivational interviewing, to reduce the risk of metabolic syndrome.
\end{abstract}

Keywords: antipsychotic; obesity; metabolic syndrome; diabetes; pediatric

\section{Introduction}

Pediatric obesity is a major public health problem. According to the Centers for Disease Control (CDC), 20.6\% of adolescents (ages 12-19) are obese. Amongst school-aged children (ages 6-11) and preschoolers (ages 2-5), obesity rates are at $18.4 \%$ and $13.9 \%$, respectively [1]. Pediatric obesity is associated with numerous medical complications including type 2 diabetes, hypertension, dyslipidemia, nonalcoholic fatty liver disease, as well as the risk of cancer in adulthood [2]. The term "metabolic syndrome (MetS)" arose to describe the clinical phenomenon of some of these complications, specifically central obesity, insulin resistance, hypertension, and dyslipidemia [2]. Specific cut-off values defining each of these features in youth, however, have not been definitively established [2]. Pediatric MetS is also strongly predictive of adult MetS and type 2 diabetes [3]. Additionally, non-alcoholic fatty liver disease (NAFLD) is associated with MetS in adults and children, and it is unclear if NAFLD is a precursor to or a manifestation of MetS [4,5].

Pediatric obesity is also linked to mental health problems, even after correcting for socioeconomic status differences. For example, obese children are more likely to have externalizing problems, grade repetition, and school problems. An association exists between obesity and ADHD, depression, and learning disabilities [6].

Pediatric obesity and MetS are major issues in the prescribing of certain psychotropic medications, particularly second-generation antipsychotics (SGA) due to significant weight gain. Youth are at higher risk of antipsychotic-induced weight gain than their adult counterparts [7]. This presents a challenging situation for prescribing clinicians. Given the complexities of pediatric obesity in general, with its numerous genetic, environmental, and medication-related factors, there are multiple intervention 
points. The same framework can be extended in the setting of SGA-induced obesity. While there are several studies and reviews encompassing adjunctive pharmacologic management of MetS in youth, to our knowledge, there have been no reviews combining the specific pathophysiology of SGA-related MetS and patient-centered lifestyle interventions [8-11]. Non-pharmacologic interventions for MetS in youth is the focus of our paper. Consensus guidelines from the American Medical Association (AMA) and CDC, endorsed by the American Academy of Pediatrics (AAP), recommend starting with non-pharmacologic lifestyle interventions in the management of pediatric obesity [12]. In this review, we deliver to clinicians prescribing SGAs to youth practical, evidence-based suggestions on lifestyle issues including diet, physical activity, sleep, stress management, and targeted nutritional supplementation in certain cases, all from a patient-centered approach. A review of pharmacologic and surgical options for the management of pediatric MetS is beyond our scope.

\section{Epidemiology of Antipsychotic-Related Metabolic Syndrome}

Currently, Federal Drug Administration-approved indications for antipsychotic prescription in youth are autism-related irritability, bipolar I disorder, and schizophrenia. Despite this, most antipsychotic prescription in youth is off-label. In the United States, it is estimated that around $66-80 \%$ of SGAs are prescribed off-label to youth with common diagnoses being Attention-Deficit/Hyperactivity Disorder (ADHD) and depression [13,14]. Among developed countries, the United States has the highest rates of antipsychotic prescription in youth [15]. Since the 1990s, rates of antipsychotic prescription in youth have somewhere between doubled and quadrupled [16]. SGA prescription in youth carries a higher risk of side effects than in the adult population in general, including weight gain [7]. Youth prescribed SGAs are also much less likely than their adult counterparts to undergo recommended monitoring of metabolic parameters [14].

Of the various longitudinal studies involving youth taking SGAs, weight gain occurs commonly. In a European trial, $53.4 \%$ of youth prescribed an SGA experienced a metabolic side effect, most commonly within the first three months of starting the medication [14]. The average weight gain over a twelve-month period was around $5 \mathrm{~kg}$, with body mass index (BMI) increasing by 1.5 points [14]. Clinically significant elevations in cholesterol occurred in about $36 \%$, and diabetes developed in about $7 \%$ in this study. A longitudinal study done in the United States between 2001 and 2007, the SATIETY trial, found that after only 10.8 weeks of SGA exposure, weight increased by $4.4-8.5 \mathrm{~kg}$, depending on the medication used [17]. The highest weight gain was associated with olanzapine ( $8.5 \mathrm{~kg})$, followed by quetiapine $(6.1 \mathrm{~kg})$, risperidone $(5.3 \mathrm{~kg})$, and finally aripiprazole $(4.4 \mathrm{~kg})$. Serum total cholesterol increased by $15.6 \mathrm{mg} / \mathrm{dL}$ (both low-density lipoprotein (LDL), and high density lipoprotein (HDL)) and triglycerides increased by $24.3 \mathrm{mg} / \mathrm{dL}$. Another cohort study between 2004 and 2006 of children ages 6-17 in a three-state Medicaid registry found that lipid disorders and diabetes were twice as common in SGA-treated youth than in the control group. Unfortunately, only $31.6 \%$ of this sample received glucose screening and only $13.4 \%$ received lipid screening [18].

Obesity is also correlated with higher risk of depressive symptoms [19-21]. In addition to psycho-social factors, there is underlying inflammation, and specifically neuro-inflammation. Central adiposity turns on a cascade of inflammatory signals like tumor necrosis factor-alpha (TNF- $\alpha$ ), interleukin-1 beta (IL-1 $\beta$ ), IL-6, and C-reactive protein that can negatively affect mood and lead to depressive symptoms [19-21].

\section{Mechanisms of Metabolic Syndrome}

The mechanisms underlying SGAs and their influence on the development of MetS are many and complex. In general, the higher the affinity to 5-hydroxytryptamine receptor $2 \mathrm{C}(5-\mathrm{HT} 2 \mathrm{C})$ and histamine $\mathrm{H} 1$ (H1) receptors, the more significant the metabolic effects, as in the case of olanzapine and clozapine [22]. Much of the literature presented in this section comes from studies of healthy volunteers and animal studies, as it can be difficult to differentiate between metabolic changes brought 
about by a given psychiatric disorder versus a psychiatric medication (i.e., depression causing a youth to become more physically inactive, eat a less healthy diet, and therefore gain weight).

Antipsychotics are known to increase appetite, which leads to weight gain [22]. There are likely multiple mechanisms for this. One mechanism is via the antipsychotic's affinity to central histamine $\mathrm{H} 1$ receptors, which exert subtle but important effects on appetite regulation and brown fat metabolism [23]. Some antipsychotics have more H1 affinity than others and therefore higher risk of weight gain. Another mechanism is through enhancing cell signaling when the hunger hormone, ghrelin, binds to its receptor [24].

SGAs can also disturb lipid profiles. Olanzapine and clozapine are known to increase triglycerides the most [25]. They increase de novo triglyceride synthesis in animal models and also up-regulate transcription factors sterol regulatory element-binding proteins (SREBP)-1 and 2, which regulate triglyceride and cholesterol synthesis [25]. Triglycerides increase in the presence of insulin-resistance due to hypersecretion of insulin, which again activates SREBP-1 and renders the body unable to inhibit the synthesis of the very low-density lipoprotein (VLDL) particles [25].

SGAs negatively impact glucose tolerance, which leads to the development of insulin resistance and type 2 diabetes mellitus [22,26]. Evidence from animal models as well as human studies suggests that the mechanisms by which SGAs contribute to insulin resistance are complex. It may occur on the level of the liver, the pancreatic beta-cells or even the autonomic nervous system [26]. Even a single dose of olanzapine in healthy adult volunteers was shown to raise fasting glucose over several hours compared to placebo [27]. Exercise may help protect against this effect: A mouse study found that "exhaustive but not moderate" exercise attenuated olanzapine's effect on raising blood glucose [28]. This effect was mediated through interleukin-6 (IL-6), suggesting that raising IL-6 in this way may be protective against hyperglycemia. Another study found that olanzapine-treated rats who exercised regularly developed less glucose intolerance that their more sedentary control counterparts [29]. Glucose Transporter 4 (GLUT4) levels were expressed in higher levels in the skeletal muscle of the more active rats; it is known that GLUT4 is an insulin-dependent transporter of glucose into cells [29]. Human studies are needed to verify if exercise can attenuate SGA-induced hyperglycemia.

There are emerging data suggesting that baseline obesity may further complicate SGA-induced glycemic effects. A study utilizing mice fed a high fat diet over four weeks found that olanzapine administration exacerbated hyperglycemia the most in the mice that were obese at baseline [30]. This suggests that obesity prior to beginning SGA therapy may compound the metabolic effects of the SGA in a direct way, although human studies replicating this finding are needed.

Genetic polymorphisms in the methylation pathway are yet another reason why some individuals are more likely to develop MetS [22]. One such polymorphism is methylenetetrahydrofolate reductase (MTHFR) with those who break down folate more slowly being at higher risk of obesity [22].

SGAs are also known to affect the gut microbiota, which is thought to lead to gut dysbiosis and weight gain [31-34]. Animal models demonstrate that fecal transplantation from risperidone-treated mice into wild-type mice causes a reduction in basal metabolic rate and significant weight gain [30]. In another study of olanzapine-treated mice, the administration of a high-dose probiotic reversed weight gain and insulin resistance [32]. In yet another study, a prebiotic mixture was shown in rats to attenuate olanzapine-induced weight gain and increase the Bacteroidetes composition in the gut, while decreasing the Firmicutes composition [33]. Bahr et al. showed an altered Firmicutes/Bacteroidetes ratio which seems to promote obesity [34]. When this analysis was repeated with male youth treated with long-term risperidone, the boys who gained the most weight had significantly fewer Bacteroidetes compared to controls [31]. It is thought that the balance between the short chain fatty acids (SCFAs) produced by these two bacterial species plays a role in fat deposition in adipose tissue [34].

Another factor that may be implicated in SGA-induced weight gain is the body's intracellular storage of iron, as measured by ferritin [35-37]. Low ferritin, indicating low bodily iron stores, is possible independent of anemia as measured by low hemoglobin and hematocrit [37]. This could be particularly relevant in youth whose bodies are growing and require sufficient intracellular iron stores [37]. 
Combining vertical growth with weight gain can deplete bodily iron stores more rapidly [37]. Studies by Calarge et al. demonstrate in children an inverse relationship between ferritin level decreases early in SGA therapy and more significant weight gain [35-37]. These results were independent of dietary iron intake, which fell within the recommended daily allowance for the study participants.

\section{Managing Metabolic Syndrome in the Setting of SGA Prescription}

There are several evidence-based, non-pharmacologic and non-surgical recommendations to prevent and manage MetS. These recommendations are meant to be suggestions for the clinician.

At the beginning of treatment:

1. Prevention. Since obesity is difficult to treat in all populations, the axiom holds true that "an ounce of prevention is worth a pound of cure." To that end, efforts have been made to reduce antipsychotic prescribing in youth and to clarify acceptable use of these medications, stressing trialing alternatives first, and to the development of guidelines around metabolic monitoring while on antipsychotics [7]. Some of these efforts have been successful, especially amongst patients of lower socioeconomic status - who perhaps are at the highest risk of obesity and MetS $[38,39]$. However, there are still situations in which the potential benefits of antipsychotic prescribing outweigh the potential risks, thus justifying ongoing SGA prescription. When possible, olanzapine and clozapine should be avoided due to these two agents having the greatest propensity to cause significant weight gain [22].

2. Provide thorough informed consent to the parent/guardian and the patient about the SGA and the extent of the metabolic risks [17]. While there are not formal guidelines about risk stratification and SGA prescription in youth, the following suggestions can be extrapolated from existing studies about risk factors for pediatric obesity in general. As part of the consent process, obtain a thorough history, including personal and family history of MetS, hypertension, dyslipidemia, obesity, diabetes, and screen for food insecurity to help identify those who may be at higher risk of developing MetS. It is possible to help address some of the risk factors preventatively.

3. Consider engaging the patient and family to make a weight management plan [26]. Utilize the tenets of motivational interviewing to discuss health goals and the plan to get there, including physical activity, food choices, screen time, and sleep.

4. For patients with specific risk factors, consider addressing those risk factors in addition to a general weight management plan [39]. Screening for food insecurity and referral to appropriate community resources may be necessary, as food insecurity is correlated with higher risk of childhood obesity [40,41]. Children with high adverse childhood experience (ACE) scores or significant family dysfunction have higher rates of obesity [40]. Referral to family therapy or facilitating engagement in additional services may be helpful [26]. Families with higher intake of processed foods or children with extremely restricted diets may benefit from a referral to a nutritionist. Children who are physically inactive should be encouraged to be more active.

5. Obtain the recommended baseline metabolic parameters, including baseline BMI, blood pressure, fasting glucose, and lipid panel. These are recommended by the American Diabetes Association (ADA), and the American Association of Child and Adolescent Psychiatry (AACAP) agrees with these recommendations [7,42]. Per American Psychiatric Society-American Diabetic Society consensus guidelines, weight should be checked every four weeks for the first three months of therapy; blood pressure and fasting lipids and blood glucose should again be checked after three months of therapy; fasting blood glucose should be obtained annually thereafter and fasting lipids every five years. Many clinicians check fasting blood glucose (or hemoglobin A1c \%) and lipids yearly.

6. "Start low and go slow" with dosing of the SGA [7]. 
Early in treatment:

1. Monitor early weight gain carefully [26]. There are some data in adults suggesting that weight gain early in therapy is predictive of continued weight gain throughout treatment [43]. If significant early weight gain occurs, defined in the cited study as $>1 \mathrm{~kg}$ in the first two weeks of therapy, forming a comprehensive weight management plan with the patient and family is especially important.

2. Continue to evaluate risks and benefits of discontinuing the SGA where possible to limit the duration of use $[7,26]$.

3. Monitor and attempt to reduce co-prescription of mood stabilizers, antidepressants, antihistamines, and other medications known to cause weight gain [7].

4. For patients requiring ongoing SGA therapy, continue to periodically review contributing lifestyle factors discussed in this paper and work on specific goals. Consider using the mnemonic "SMART" (specific, measurable, achievable, relevant, time-limited) to help the patient set and achieve their goals.

5. Consider targeted, evidence-based supplementation for various aspects of MetS that may develop as a result of SGA therapy, the evidence for which is discussed below.

\subsection{Recommendations for Making Better Food Choices}

\subsubsection{Mediterranean Diet}

The American Heart Association (AHA) recommends a Mediterranean-type diet to youth in general and specifically for those who are obese [44]. This dietary pattern emphasizes the intake of vegetables, fruits, whole grains, low-fat and nonfat dairy products, means, fish, and lean meat [44]. Youth who adhere the closest to a Mediterranean diet have lower rates of obesity and MetS $[45,46]$. The Mediterranean diet can be a helpful intervention in the treatment of non-alcoholic fatty liver disease (NAFLD) [47]. For younger children, using a traffic light dietary pattern may be helpful in dividing foods into "green light" (fruits, vegetables), "yellow light" (grains), and "red light" (least nutrient-dense, highest calories), and limiting "red light" foods to a certain number per week may be helpful [48].

As an additional benefit, the Mediterranean diet is likely protective against depression $[49,50]$. In adults with MetS, dietary patterns closest to the Mediterranean diet are correlated with lower rates of depressive symptoms [49]. Diets high in processed food and low in vegetables and fruits-the opposite of the Mediterranean diet-are predictive of depressive symptoms in youth as well [50].

\subsubsection{Dietary Fiber Consumption}

Increased fiber consumption is linked to improved insulin sensitivity and to lower hemoglobin A1c percentages in patients with diabetes and pre-diabetes [51]. An increase in dietary fiber is one of the first-line interventions in the treatment of NAFLD as well [47]. For children, to calculate the recommended daily fiber intake, clinicians can use the "age plus 5" formula [48]. Fiber intake for a ten-year-old child, for example, should be $15 \mathrm{~g}$ daily [48]. By the time children reach age 15, their fiber intake should be at adult levels [48]. Assuming an average fiber intake of around $20 \mathrm{~g}$ daily for an adult, Reynolds et al. recommended from their findings that increasing daily fiber intake to 35-40 $\mathrm{g}$ daily significantly improved insulin sensitivity [51]. A good way to get more fiber is to simply replace refined grain products in the diet with whole grain products [51].

\subsubsection{Low-Glycemic Foods}

Consumption of low-glycemic foods reduces post-prandial glucose rise and insulin spikes, resulting in better diabetes control according to a recent meta-analysis [52]. Specific suggestions might include substituting oatmeal for cereal at breakfast, brown rice for white rice, sweet potatoes for white 
potatoes, incorporating at least one vegetable at each meal, and eliminating processed foods like chips, candy, etc. [48]. Teaching patients to read food labels to identify the addition of sugars into sauces and dressings and to avoid products containing high fructose corn syrup (HFCS) as regular consumption of HFCS is linked with obesity and MetS [53-55].

\subsubsection{Reduce Intake of Sugar-Sweetened Beverages}

Sugar-sweetened beverages (SSBs) (e.g., sodas and juices) are clearly associated with obesity in children and adolescents [16]. A Cochrane Review examined the efficacy of various interventions in reducing the consumption of SSB [56]. Interventions in that review with the highest evidence included food labeling, price increases on SSBs, restricting SSBs from the food stamp program-all of which indicate the importance of food policy in combating pediatric obesity. On an individual level, one of the best interventions from the Cochrane review to help obese adolescents reduce SSB consumption is for parents to put low-calorie drink options in their home to replace SSBs.

\subsubsection{Breakfast and Food Timing}

Some evidence points to a correlation between obesity risk and breakfast skipping in children and adolescents [48]. Eating breakfast may lead to less snacking and smaller portion sizes at meals during the rest of the day [48]. Research is emerging about the relationship between obesity and the timing of meals in general, the regular scheduling of mealtimes, ranging from time of day a meal is consumed to time-restricted fasting; however, there are not pediatric-focused studies on these topics to our knowledge [57-60]. The macronutrient profile of food eaten prior to bedtime may also play a role in metabolism and the development of obesity, according to at least one mouse study involving concentrating carbohydrate intake before sleep. In this study, obese mice fed most of their daily carbohydrates prior to bedtime ate less, were leaner, and lost fat mass compared to obese mice fed carbohydrates consistently throughout the day [61]. Designing a follow-up study in human subjects, and then in youth, is needed.

\subsubsection{Mindfulness at Meals}

Mindful eating can simultaneously increase food-related pleasure and reduce total calories consumed and reduce emotional eating [62]. However, studies are needed examining the effects of mealtime mindfulness interventions in obese youth.

\subsection{Recommendations for Increasing Physical Activity}

Increasing physical activity is near the top of the list of interventions in the treatment of pediatric obesity, second only to dietary intervention [48]. Many studies have shown that increasing physical activity for youth leads to a reduction in BMI [48]. Combining aerobic training and resistance training over a longer time period leads to the most significant reductions in BMI in youth according to a recent meta-analysis [63]. The CDC recommends that children and adolescents engage in $60 \mathrm{~min}$ of moderate-to-vigorous physical activity daily. However, that is not the reality for the majority in the United States, regardless of obesity status; only an estimated $24 \%$ of youth achieve that level of physical activity [64].

Instead of using the word "exercise", we suggest using words like "movement" to further generalize the concept of being more active, which can include dancing, yoga, walking, stretching. One of the first steps in becoming more physically active might be reducing sedentary time, which tends to mean screen time for children and adolescents: in 2010, children and adolescents spent more than seven and a half hours daily in front of a screen [65].

As an additional benefit, physical activity is associated with fewer depressive symptoms and functions as a treatment for adolescent depressive symptoms of moderate effect size according to several meta analyses $[66,67]$. 


\subsection{Recommendations for Healthy Sleep}

Sleep disturbances are very common amongst children and adolescents with psychiatric disorders and are often at the core of the diagnosis [68]. Sleep disturbances also have metabolic consequences. The link between insufficient sleep and obesity and type 2 diabetes is well-established, both in adult and pediatric literature $[69,70]$. Short sleep duration conferred a $58 \%$ higher risk for obesity or overweight in one meta-analysis [71]. Authors also found a $92 \%$ increase in risk of obesity or overweight amongst children with the shortest sleep duration compared to children who slept longer. Most strikingly, for each additional hour of sleep, there was a $9 \%$ reduction in the risk of overweight or obesity [71]. Another study found that, after controlling for demographic factors, later adolescent bedtimes were associated with higher total daily fat intake, later first and last meals of the day, and greater after-dinner intake [72]. Conversely, earlier bedtimes are particularly helpful in reducing caloric intake in children and adolescents $[73,74]$. Guidelines from the National Sleep Foundation, endorsed by the American Academy of Pediatrics, suggest 10-13 hours (h) of sleep for preschoolers (ages 3-5), 9-11 h for school age children (6-13), and 8-10 $\mathrm{h}$ for teenagers (14-17). In addition to sufficient sleep and earlier bedtimes, additional sleep hygiene improvements may be indicated such as creating a soothing bedtime routine, restricting access to electronic devices within two hours of bedtime, limiting naps, keeping the sleeping environment dark and cool, and ensuring the youth uses their bed for sleep only [54,75].

Clinicians should also be especially attuned to medical conditions interfering with sleep as sleep disorders are also more common in patients with psychiatric disorders. Obstructive sleep apnea in the pediatric population is associated with higher risk of diabetes independent of obesity [76]. Restless leg syndrome is more prevalent in obese youth and can negatively impact sleep quality as well [77].

\subsection{Recommendations for Stress Management}

While mindfulness interventions related to prevention of obesity are in their infancy, one pilot trial for at-risk adolescents in a mindfulness group versus a health education control group did not find any evidence that BMI measurements were different between the two groups at the end of the six-week intervention [78]. Other mindfulness interventions such as mindfulness-based eating awareness training for the individual and/or family, breathwork training, and school-based mindfulness-based stress reduction (MBSR) training, targeting eating behaviors in adolescents have showed promising results [79].

\subsection{Evidence-Based Supplementation for Metabolic Syndrome}

\subsubsection{Vitamin D}

Hypovitaminosis D is a predictor of cardiovascular mortality. In children, optimizing vitamin D is correlated with improvements in lipid profile, specifically in improving HDL [80,81]. Endocrine Society Guidelines recommend 25(OH)D levels $\geq 30 \mathrm{ng} / \mathrm{mL}$ [82].

\subsubsection{Omega 3 Fatty Acids for Hypertriglyceridemia}

Supplementing with omega 3 fatty acids in the form of fish oil (3 grams daily) was found in a recent randomized, double-blind, placebo-controlled trial in children and adolescents to reduce serum triglycerides by $39 \%$ compared to $16 \%$ in placebo $(p<0.01)$ [83]. There are numerous other studies in the pediatric literature demonstrating similar results. In addition to triglyceride lowering properties, omega-3 supplementation has an evidence base in treating symptoms of ADHD, bipolar disorder, and depression, all of which can be off-label indications for SGA prescription [84-88].

\subsubsection{Alpha-Lipoic Acid (ALA) for Weight Loss}

A recent randomized, double-blind, placebo-controlled trial of obese youth $(n=80)$ found that supplementation of ALA 300 milligrams twice daily for three months significantly improved BMI over 
the control group $(p<0.05)$ although lipid profiles did not improve [89]. It is known that ALA exerts anti-inflammatory benefits [89].

\subsubsection{Other Supplements}

Probiotic supplementation, while shown to be helpful in attenuating weight gain in animal models as described above, does not yet have an evidence base in youth prescribed SGAs. Moreover, as described above, lower ferritin levels were correlated with risperidone-induced weight gain in boys; however, no studies show that supplementing with iron attenuates weight gain. Obese children tend to have lower serum magnesium levels, which was correlated in one study with lower insulin sensitivity [90]. No studies have examined magnesium supplementation in youth as a treatment for obesity or insulin resistance. Chromium supplementation in adults can reduce hemoglobin $\mathrm{A} 1 \mathrm{c} \%$; however, there is not an evidence base for its use in the pediatric population [91]. Similarly, zinc supplementation may play a protective role against diabetes in adults, but studies are lacking in youth [92].

Myo-inositol has an evidence base in reducing BMI in women with polycystic ovarian syndrome (PCOS) and in obese patients with fasting plasma insulin levels but has not been studied in youth [93]. Herbs such as berberine and ginseng, which have an evidence base in adults with insulin resistance, have not been studied in the pediatric population and are thus not currently recommended [94,95].

\section{Conclusions}

The metabolic side effects of SGAs in youth are significant and can have far-reaching consequences into adulthood. Clinicians who prescribe SGAs should carefully weigh risks and benefits of prescribing, reserving prescription for cases in which the benefits clearly outweigh risks. We also recommend that clinicians educate patients and their families about metabolic risks of SGAs and that this education be ongoing, not just at the start of therapy. We suggest that clinicians take a motivational interviewing approach to identify modifiable lifestyle factors that are risks for the development of obesity and MetS and to create specific goals, taking into account various risk factors including medical history, family history, family lifestyle, and socioeconomic factors. Interventions with the most evidence include increasing consumption of fruits, vegetables, and whole grains, increasing physical activity, improving sleep, and fish oil supplementation. While outside the scope of this review, certain pharmacologic interventions such as metformin may be indicated as well; however, they are best done as adjunctive to lifestyle changes. Finally, the mental health benefits of treating obesity should not be overlooked. Treating obesity is associated with a reduction in depressive and anxious symptoms in the pediatric population [96].

Future directions for research should include a clearer definition of the exact cut-off values to establish the diagnosis of MetS; additional innovative and cost-effective behavioral intervention trials focusing on lifestyle choices; and the establishment of a more in-depth understanding of the interplay between chronic stress, trauma, and metabolism.

In conclusion, the prescription of an SGA offers the opportunity to work collaboratively with the patient and their family to improve overall health and to mitigate potential serious side effects-an opportunity that should not be missed.

Author Contributions: Conceptualization, U.R. and J.R.; literature review, J.R. and U.R.; writing-original draft preparation, J.R.; writing — review and editing, U.R.; writing—revisions, J.R. and U.R. All authors have read and agreed to the published version of the manuscript.

Funding: This review received no external funding.

Conflicts of Interest: The authors declare no conflict of interest.

\section{References}

1. Hales, C.M.; Carroll, M.D.; Fryar, C.D.; Ogden, C.L. Prevalence of Obesity Among Adults and Youth: United States, 2015-2016. NCHS Data Briefs 2017. 
2. Weihe, P.; Weihrauch-Blüher, S. Metabolic Syndrome in Children and Adolescents: Diagnostic Criteria, Therapeutic Options and Perspectives. Curr. Obes. Rep. 2019, 8, 472-479. [CrossRef] [PubMed]

3. Morrison, J.A.; Friedman, L.A.; Wang, P.; Glueck, C.J. Metabolic Syndrome in Childhood Predicts Adult Metabolic Syndrome and Type 2 Diabetes Mellitus 25 to 30 Years Later. J. Pediatr. 2008, 152, 201-206. [CrossRef] [PubMed]

4. Lonardo, A.; Ballestri, S.; Marchesini, G.; Angulo, P.; Loria, P. Nonalcoholic fatty liver disease: A precursor of the metabolic syndrome. Dig. Liver Dis. 2015, 47, 181-190. [CrossRef]

5. Clemente, M.G.; Mandato, C.; Poeta, M.; Vajro, P. Pediatric non-alcoholic fatty liver disease: Recent solutions, unresolved issues, and future research directions. World J. Gastroenterol. 2016, 22, 8078-8093. [CrossRef]

6. Halfon, N.; Larson, K.; Slusser, W. Associations Between Obesity and Comorbid Mental Health, Developmental, and Physical Health Conditions in a Nationally Representative Sample of US Children Aged 10 to 17. Acad. Pediatr. 2013, 13, 6-13. [CrossRef]

7. Barthel, R.P. The American Academy of Child and Adolescent Psychiatry. Acad. Psychiatry 2007, 31, $119-121$. [CrossRef]

8. Fornari, E.; Maffeis, C. Treatment of Metabolic Syndrome in Children. Front. Endocrinol. 2019, $10,702$. [CrossRef]

9. Raub, R.M.; Goldberg, S.J. Assessment of Metformin as an Additional Treatment to Therapeutic Lifestyle Changes in Pediatric Patients with Metabolic Syndrome. Cholesterol 2012, 2012, 1-5. [CrossRef]

10. Anagnostou, E.; Aman, M.G.; Handen, B.L.; Sanders, K.B.; Shui, A.; Hollway, J.A.; Brian, J.; Arnold, L.E.; Capano, L.; Hellings, J.A.; et al. Metformin for Treatment of Overweight Induced by Atypical Antipsychotic Medication in Young People with Autism Spectrum Disorder. JAMA Psychiatry 2016, 73, 928-937. [CrossRef]

11. Andrade, C. Metformin as a Possible Intervention for Cardiometabolic Risks in Pediatric Subjects Exposed to Antipsychotic Drugs. J. Clin. Psychiatry 2016, 77, 1362-1364. [CrossRef]

12. Barlow, S.E. The Expert Committee Expert Committee Recommendations Regarding the Prevention, Assessment, and Treatment of Child and Adolescent Overweight and Obesity: Summary Report. Pediatrics 2007, 120, 164-192. [CrossRef]

13. Sohn, M.; Moga, D.C.; Blumenschein, K.; Talbert, J. National trends in off-label use of atypical antipsychotics in children and adolescents in the United States. Medicine 2016, 95, e3784. [CrossRef]

14. Menard, M.-L.; Thümmler, S.; Giannitelli, M.; Cruzel, C.; Bonnot, O.; Cohen, D.; Askenazy, F.; Boublil, M.; Chambry, J.; Charvet, D.; et al. Incidence of adverse events in antipsychotic-naïve children and adolescents treated with antipsychotic drugs: Results of a multicenter naturalistic study (ETAPE). Eur. Neuropsychopharmacol. 2019, 29, 1397-1407. [CrossRef] [PubMed]

15. Kalverdijk, L.J.; Bachmann, C.J.; Aagaard, L.; Burcu, M.; Glaeske, G.; Hoffmann, F.; Petersen, I.; Schuiling-Veninga, C.C.; Wijlaars, L.; Zito, J.M. A multi-national comparison of antipsychotic drug use in children and adolescents, 2005-2012. Child Adolesc. Psychiatry Ment. Health 2017, 11, 55. [CrossRef] [PubMed]

16. Ronsley, R.; Scott, D.; Warburton, W.P.; Hamdi, R.D.; Louie, D.C.; Davidson, J.; Panagiotopoulos, C. A population-based study of antipsychotic prescription trends in children and adolescents in British Columbia, from 1996 to 2011. Can. J. Psychiatry 2013, 58, 361-369. [CrossRef] [PubMed]

17. Correll, C.U.; Manu, P.; Olshanskiy, V.; Napolitano, B.; Kane, J.M.; Malhotra, A.K. Cardiometabolic Risk of Second-Generation Antipsychotic Medications During First-Time Use in Children and Adolescents. JAMA 2009, 302, 1765-1773. [CrossRef] [PubMed]

18. Morrato, E.H.; Nicol, G.E.; Maahs, D.; Druss, B.G.; Hartung, D.M.; Valuck, R.J.; Campagna, E.; Newcomer, J.W. Metabolic Screening in Children Receiving Antipsychotic Drug Treatment. Arch. Pediatr. Adolesc. Med. 2010, 164, 344-351. [CrossRef]

19. Castanon, N.; Luheshi, G.; Laye, S. Role of neuroinflammation in the emotional and cognitive alterations displayed by animal models of obesity. Front. Mol. Neurosci. 2015, 9, 1-14. [CrossRef]

20. Rossetti, C.; Halfon, O.; Boutrel, B. Controversies about a common etiology for eating and mood disorders. Front. Psychol. 2014, 5, 1-19. [CrossRef]

21. Hryhorczuk, C.; Sharma, S.; Fulton, S.E. Metabolic disturbances connecting obesity and depression. Front. Mol. Neurosci. 2013, 7, 1-14. [CrossRef] [PubMed]

22. Singh, R.; Bansal, Y.; Medhi, B.; Kuhad, A. Antipsychotics-induced metabolic alterations: Recounting the mechanistic insights, therapeutic targets and pharmacological alternatives. Eur. J. Pharmacol. 2019, 844, 231-240. [CrossRef] [PubMed] 
23. Teff, K.L.; Kim, S.F. Atypical antipsychotics and the neural regulation of food intake and peripheral metabolism. Physiol. Behav. 2011, 104, 590-598. [CrossRef] [PubMed]

24. Tagami, K.; Kashiwase, Y.; Yokoyama, A.; Nishimura, H.; Miyano, K.; Suzuki, M.; Shiraishi, S.; Matoba, M.; Ohe, Y.; Uezono, Y. The atypical antipsychotic, olanzapine, potentiates ghrelin-induced receptor signaling: An in vitro study with cells expressing cloned human growth hormone secretagogue receptor. Neuropeptides 2016, 58, 93-101. [CrossRef]

25. Yan, H.; Chen, J.-D.; Zheng, X.-Y. Potential mechanisms of atypical antipsychotic-induced hypertriglyceridemia. Psychopharmacology 2013, 229, 1-7. [CrossRef] [PubMed]

26. Kowalchuk, C.; Castellani, L.N.; Chintoh, A.; Remington, G.; Giacca, A.; Hahn, M.K. Antipsychotics and glucose metabolism: How brain and body collide. Am. J. Physiol.-Endocrinol. Metab. 2019, 316, E1-E15. [CrossRef]

27. Hahn, M.K.; Wolever, T.M.; Arenovich, T.; Teo, C.; Giacca, A.; Powell, V.; Clarke, L.; Fletcher, P.; Cohn, T.; McIntyre, R.S.; et al. Acute Effects of Single-Dose Olanzapine on Metabolic, Endocrine, and Inflammatory Markers in Healthy Controls. J. Clin. Psychopharmacol. 2013, 33, 740-746. [CrossRef]

28. Castellani, L.N.; Peppler, W.T.; Miotto, P.M.; Bush, N.; Wright, D.C. Exercise Protects Against Olanzapine-Induced Hyperglycemia in Male C57BL/6J Mice. Sci. Rep. 2018, 8, 1-11. [CrossRef]

29. Boyda, H.N.; Ramos-Miguel, A.; Procyshyn, R.M.; Töpfer, E.; Lant, N.; Choy, H.H.T.; Wong, R.; Li, L.; Pang, C.C.Y.; Honer, W.G.; et al. Routine exercise ameliorates the metabolic side-effects of treatment with the atypical antipsychotic drug olanzapine in rats. Int. J. Neuropsychopharmacol. 2013, 17, 77-90. [CrossRef]

30. Townsend, L.K.; Peppler, W.T.; Bush, N.D.; Wright, D.C. Obesity exacerbates the acute metabolic side effects of olanzapine. Psychoneuroendocrinology 2018, 88, 121-128. [CrossRef]

31. Bahra, S.M.; Weidemann, B.J.; Castro, A.N.; Walsh, J.W.; DeLeon, O.; Burnett, C.M.; Pearson, N.A.; Murry, D.J.; Grobe, J.L.; Kirby, J.R.; et al. Risperidone-induced weight gain is mediated through shifts in the gut microbiome and suppression of energy expenditure. EBioMedicine 2015, 2, 1725-1734. [CrossRef] [PubMed]

32. Dhaliwal, N.; Dhaliwal, J.; Singh, D.P.; Kondepudi, K.K.; Bishnoi, M.; Chopra, K. The Probiotic Mixture VSL\#3 Reverses Olanzapine-Induced Metabolic Dysfunction in Mice. Methods Mol. Biol. 2019, 2011, 531-544. [CrossRef] [PubMed]

33. Kao, A.C.-C.; Spitzer, S.; Anthony, D.C.; Lennox, B.R.; Burnet, P. Prebiotic attenuation of olanzapine-induced weight gain in rats: Analysis of central and peripheral biomarkers and gut microbiota. Transl. Psychiatry 2018, 8, 1-12. [CrossRef] [PubMed]

34. Skonieczna-Żydecka, K.; Łoniewski, I.; Misera, A.; Stachowska, E.; Maciejewska, D.; Marlicz, W.; Galling, B. Second-generation antipsychotics and metabolism alterations: A systematic review of the role of the gut microbiome. Psychopharmacology 2018, 236, 1491-1512. [CrossRef]

35. Calarge, C.A.; Ziegler, E.E. Iron Deficiency in Pediatric Patients in Long-Term Risperidone Treatment. J. Child Adolesc. Psychopharmacol. 2013, 23, 101-109. [CrossRef]

36. Calarge, C.A.; Ziegler, E.E.; Del Castillo, N.; Aman, M.; McDougle, C.J.; Scahill, L.; McCracken, J.T.; Arnold, L.E. Iron homeostasis during risperidone treatment in children and adolescents. J. Clin. Psychiatry 2015, 76, 1500-1505. [CrossRef]

37. Calarge, C.A.; Murry, D.J.; Ziegler, E.E.; Arnold, L.E. Serum Ferritin, Weight Gain, Disruptive Behavior, and Extrapyramidal Symptoms in Risperidone-Treated Youth. J. Child Adolesc. Psychopharmacol. 2016, 26, 471-477. [CrossRef]

38. Park, S.Y.; Cervesi, C.; Galling, B.; Molteni, S.; Walyzada, F.; Ameis, S.H.; Gerhard, T.M.; Olfson, M.; Correll, C.U. Antipsychotic Use Trends in Youth with Autism Spectrum Disorder and/or Intellectual Disability: A Meta-Analysis. J. Am. Acad. Child Adolesc. Psychiatry 2016, 55, 456-468. [CrossRef]

39. SAMHSA. Guidance on Strategies to Promote Best Practice in Antipsychotic Prescribing for Children and Adolescents; SAMHSA: Rockville, MD, USA, 2019.

40. Hemmingsson, E. Early Childhood Obesity Risk Factors: Socioeconomic Adversity, Family Dysfunction, Offspring Distress, and Junk Food Self-Medication. Curr. Obes. Rep. 2018, 7, 204-209. [CrossRef]

41. Nagata, J.M.; Palar, K.; Gooding, H.C.; Garber, A.K.; Bibbins-Domingo, K.; Weiser, S.D. Food Insecurity and Chronic Disease in US Young Adults: Findings from the National Longitudinal Study of Adolescent to Adult Health. J. Gen. Intern. Med. 2019, 34, 2756-2762. [CrossRef] 
42. American Diabetes Association; American Psychiatric Association; American Association of Clinical Endocrinologists; North American Association for the Study of Obesity. Consensus Development Conference on Antipsychotic Drugs and Obesity and Diabetes. Diabetes Care 2004, 27, 596-601. [CrossRef] [PubMed]

43. Lin, C.-H.; Lin, S.-C.; Huang, Y.-H.; Wang, F.-C.; Huang, C.-J. Early prediction of olanzapine-induced weight gain for schizophrenia patients. Psychiatry Res. 2018, 263, 207-211. [CrossRef] [PubMed]

44. Gidding, S.S.; Dennison, B.A.; Birch, L.L.; Daniels, S.R.; Gilman, M.W.; Lichtenstein, A.H.; Rattay, K.T.; Steinberger, J.; Stettler, N.; Van Horn, L. Dietary Recommendations for Children and Adolescents. Circulation 2005, 112, 2061-2075. [CrossRef]

45. Katsagoni, C.N.; Psarra, G.; Georgoulis, M.; Tambalis, K.D.; Panagiotakos, D.B.; Sidossis, L.S.; ErZHN Study Group. High and moderate adherence to Mediterranean lifestyle is inversely associated with overweight, general and abdominal obesity in children and adolescents: The MediLIFE-index. Nutr. Res. 2020, 73, 38-47. [CrossRef]

46. Velázquez-López, L.; Santiago-Díaz, G.; Nava-Hernández, J.; Muñoz-Torres, A.V.; Medina-Bravo, P.; Torres-Tamayo, M. Mediterranean-style diet reduces metabolic syndrome components in obese children and adolescents with obesity. BMC Pediatr. 2014, 14, 175. [CrossRef] [PubMed]

47. Mundi, M.S.; Velapati, S.; Patel, J.; Kellogg, T.A.; Abu Dayyeh, B.K.; Hurt, R.T. Evolution of NAFLD and Its Management. Nutr. Clin. Pract. 2019, 35, 72-84. [CrossRef] [PubMed]

48. Spear, B.A.; Barlow, S.E.; Ervin, C.; Ludwig, D.S.; Saelens, B.E.; Schetzina, K.E.; Taveras, E.M. Recommendations for Treatment of Child and Adolescent Overweight and Obesity. Pediatrics 2007, 120, S254-S288. [CrossRef] [PubMed]

49. García-Toro, M.; Vicens-Pons, E.; Gili, M.; Roca, M.; Serrano-Ripoll, M.J.; Vives, M.; Leiva, A.; Yañez, A.M.; Bennasar-Veny, M.; Oliván-Blázquez, B. Obesity, metabolic syndrome and Mediterranean diet: Impact on depression outcome. J. Affect. Disord. 2016, 194, 105-108. [CrossRef]

50. Kim, T.-H.; Choi, J.-Y.; Lee, H.-H.; Park, Y.S. Associations between Dietary Pattern and Depression in Korean Adolescent Girls. J. Pediatr. Adolesc. Gynecol. 2015, 28, 533-537. [CrossRef]

51. Reynolds, A.N.; Akerman, A.P.; Mann, J. Dietary fibre and whole grains in diabetes management: Systematic review and meta-analyses. PLoS Med. 2020, 17, e1003053. [CrossRef]

52. Zafar, M.I.; Mills, K.; Zheng, J.; Regmi, A.; Hu, S.Q.; Gou, L.; Chen, L.-L. Low-glycemic index diets as an intervention for diabetes: A systematic review and meta-analysis. Am. J. Clin. Nutr. 2019, 110, 891-902. [CrossRef] [PubMed]

53. Tappy, L. Fructose-containing caloric sweeteners as a cause of obesity and metabolic disorders. J. Exp. Biol. 2018, 221, jeb164202. [CrossRef] [PubMed]

54. Basaranoglu, M.; Basaranoglu, G.; Sabuncu, T.; Senturk, H. Fructose as a key player in the development of fatty liver disease. World J. Gastroenterol. 2013, 19, 1166-1172. [CrossRef] [PubMed]

55. Gugliucci, A. Fructose at the crossroads of the metabolic syndrome and obesity epidemics. Front. Biosci. 2019, 24, 186-211. [CrossRef]

56. von Philipsborn, P.; Stratil, J.M.; Burns, J.; Busert, L.K.; Pfadenhauer, L.M.; Polus, S.; Holzapfel, C.; Hauner, H.; Rehfuess, E. Environmental interventions to reduce the consumption of sugar-sweetened beverages and their effects on health. Cochrane Database Syst. Rev. 2019, 6. [CrossRef]

57. Ha, K.; Song, Y. Associations of Meal Timing and Frequency with Obesity and Metabolic Syndrome among Korean Adults. Nutrients 2019, 11, 2437. [CrossRef]

58. Singh, R.; Cornelissen, G.; Mojto, V.; Fatima, G.; Wichansawakun, S.; Singh, M.; Kartikey, K.; Sharma, J.P.; Torshin, V.I.; Chibisov, S.; et al. Effects of circadian restricted feeding on parameters of metabolic syndrome among healthy subjects. Chronobiol. Int. 2020, 37, 395-402. [CrossRef]

59. Pot, G.K.; Almoosawi, S.; Stephen, A.M. Meal Irregularity and Cardiometabolic Consequences: Results from Observational and Intervention Studies. Proc. Nutr. Soc. 2016, 75, 475-486. [CrossRef]

60. Kosmadopoulos, A.; Kervezee, L.; Boudreau, P.; Gonzales-Aste, F.; Vujovic, N.; Scheer, F.A.J.L.; Boivin, D.B. Effects of Shift Work on the Eating Behavior of Police Officers on Patrol. Nutrients 2020, 12, 999. [CrossRef]

61. Sofer, S.; Eliraz, A.; Madar, Z.; Froy, O. Concentrating carbohydrates before sleep improves feeding regulation and metabolic and inflammatory parameters in mice. Mol. Cell. Endocrinol. 2015, 414, 29-41. [CrossRef]

62. Schnepper, R.; Richard, A.; Wilhelm, F.; Blechert, J. A combined mindfulness-prolonged chewing intervention reduces body weight, food craving, and emotional eating. J. Consult. Clin. Psychol. 2019, 87, 106-111. [CrossRef] 
63. García-Hermoso, A.; Ramírez-Vélez, R.; Ramírez-Campillo, R.; Peterson, M.D.; Solera-Martínez, M. Concurrent aerobic plus resistance exercise versus aerobic exercise alone to improve health outcomes in paediatric obesity: A systematic review and meta-analysis. Br. J. Sports Med. 2016, 52, 161-166. [CrossRef] [PubMed]

64. The Child \& Adolescent Health Measurement Initiative (CAHMI). 2016 National Survey of Childrens' Health; Data Resource Center for Child and Adolescent Health: Baltimore, MD, USA, 2016.

65. Rideout, V.J.; Foehr, U.G.; Roberts, D.F. Generation M2: Media in the Lives of 8- to 18-Year-Olds; Henry J. Kaiser Family Foundation: Menlo Park, CA, USA, 2010.

66. Korczak, D.J.; Madigan, S.; Colasanto, M. Children's Physical Activity and Depression: A Meta-analysis. Pediatrics 2017, 139, e20162266. [CrossRef] [PubMed]

67. Oberste, M.; Medele, M.; Javelle, F.; Wunram, H.L.; Walter, D.; Bloch, W.; Bender, S.; Fricke, O.; Joisten, N.; Walzik, D.; et al. Physical Activity for the Treatment of Adolescent Depression: A Systematic Review and Meta-Analysis. Front. Physiol. 2020, 11. [CrossRef] [PubMed]

68. Ramtekkar, U.; Ivanenko, A. Sleep in Children with Psychiatric Disorders. Semin. Pediatr. Neurol. 2015, 22, 148-155. [CrossRef] [PubMed]

69. Reutrakul, S.; Van Cauter, E. Sleep influences on obesity, insulin resistance, and risk of type 2 diabetes. Metabolism 2018, 84, 56-66. [CrossRef]

70. Nedeltcheva, A.V.; Scheer, F.A.J.L. Metabolic effects of sleep disruption, links to obesity and diabetes. Curr. Opin. Endocrinol. Diabetes Obes. 2014, 21, 293-298. [CrossRef]

71. Chen, X.; Beydoun, M.A.; Wang, Y. Is Sleep Duration Associated with Childhood Obesity? A Systematic Review and Meta-analysis. Obesity 2008, 16, 265-274. [CrossRef]

72. Spaeth, A.M.; Hawley, N.L.; Raynor, H.A.; Jelalian, E.; Greer, A.; Crouter, S.E.; Coffman, D.L.; Carskadon, M.A.; Owens, J.A.; Wing, R.R.; et al. Sleep, energy balance, and meal timing in school-aged children. Sleep Med. 2019, 60, 139-144. [CrossRef]

73. Thellman, K.E.; Dmitrieva, J.; Miller, A.L.; Harsh, J.R.; LeBourgeois, M.K. Sleep timing is associated with self-reported dietary patterns in 9- to 15-year-olds. Sleep Health 2017, 3, 269-275. [CrossRef]

74. Asarnow, L.D.; Greer, S.M.; Walker, M.P.; Harvey, A.G. The impact of sleep improvement on food choices in Adolescents with Late Bedtimes. J. Adolesc. Health 2018, 60, 570-576. [CrossRef] [PubMed]

75. HealthyChildren.org. Sleep Tips for Your Family's Mental Health. Available online: https:// www.healthychildren.org/English/healthy-living/sleep/Pages/Sleep-and-Mental-Health.aspx (accessed on 11 August 2020).

76. Siriwat, R.; Wang, M.L.; Shah, V.; Mehra, R.; Ibrahim, S. Obstructive Sleep Apnea and Insulin Resistance in Obese Children. J. Clin. Sleep Med. 2020. [CrossRef] [PubMed]

77. Baran, R.T.; Atar, M.; Pirgon, Ö.; Filiz, S.; Filiz, M.B. Restless Legs Syndrome and Poor Sleep Quality in Obese Children and Adolescents. J. Clin. Res. Pediatr. Endocrinol. 2018, 10, 131-138. [CrossRef] [PubMed]

78. Shomaker, L.B.; Berman, Z.; Burke, M.; Annameier, S.K.; Pivarunas, B.; Sanchez, N.; Smith, A.D.; Hendrich, S.; Riggs, N.R.; Legget, K.T.; et al. Mindfulness-based group intervention in adolescents at-risk for excess weight gain: A randomized controlled pilot study. Appetite 2019, 140, 213-222. [CrossRef] [PubMed]

79. Omiwole, M.; Richardson, C.; Huniewicz, P.; Dettmer, E.; Paslakis, G. Review of Mindfulness-Related Interventions to Modify Eating Behaviors in Adolescents. Nutrients 2019, 11, 2917. [CrossRef] [PubMed]

80. Kelishadi, R.; Farajzadegan, Z.; Bahreynian, M. Association between vitamin D status and lipid profile in children and adolescents: A systematic review and meta-analysis. Int. J. Food Sci. Nutr. 2014, 65, 404-410. [CrossRef]

81. Tavakoli, F.; Namakin, K.; Zardast, M. Vitamin D Supplementation and High-Density Lipoprotein Cholesterol: A Study in Healthy School Children. Iran. J. Pediatr. 2016, 26. [CrossRef]

82. Holick, M.F.; Binkley, N.; Bischoff-Ferrari, H.A.; Gordon, C.M.; Hanley, D.A.; Heaney, R.P.; Murad, M.H.; Weaver, C.M. Evaluation, Treatment, and Prevention of Vitamin D Deficiency: An Endocrine Society Clinical Practice Guideline. J. Clin. Endocrinol. Metab. 2011, 96, 1911-1930. [CrossRef]

83. Del-Río-Navarro, B.E.; Miranda-Lora, A.L.; Huang, F.; Hall-Mondragon, M.S.; Leija-Martínez, J.J. Effect of supplementation with omega-3 fatty acids on hypertriglyceridemia in pediatric patients with obesity. J. Pediatr. Endocrinol. Metab. 2019, 32, 811-819. [CrossRef] 
84. Chang, J.P.-C.; Su, K.-P.; Mondelli, V.; Pariante, C.M. Omega-3 Polyunsaturated Fatty Acids in Youths with Attention Deficit Hyperactivity Disorder: A Systematic Review and Meta-Analysis of Clinical Trials and Biological Studies. Neuropsychopharmacology 2017, 43, 534-545. [CrossRef]

85. Cooper, R.E.; Tye, C.; Kuntsi, J.; Vassos, E.; Asherson, P. The effect of omega-3 polyunsaturated fatty acid supplementation on emotional dysregulation, oppositional behaviour and conduct problems in ADHD: A systematic review and meta-analysis. J. Affect. Disord. 2016, 190, 474-482. [CrossRef] [PubMed]

86. Sarris, J.; Mischoulon, D.; Schweitzer, I. Omega-3 for Bipolar Disorder. J. Clin. Psychiatry 2011, 73, 81-86. [CrossRef] [PubMed]

87. Liao, Y.; Xie, B.; Zhang, H.; He, Q.; Guo, L.; Subramaniapillai, M.; Fan, B.; Lu, C.-Y.; Mclntyer, R.S. Efficacy of omega-3 PUFAs in depression: A meta-analysis. Transl. Psychiatry 2019, 9, 190-199. [CrossRef] [PubMed]

88. Martins, J.G. EPA but Not DHA Appears to Be Responsible for the Efficacy of Omega-3 Long Chain Polyunsaturated Fatty Acid Supplementation in Depression: Evidence from a Meta-Analysis of Randomized Controlled Trials. J. Am. Coll. Nutr. 2009, 28, 525-542. [CrossRef] [PubMed]

89. El Amrousy, D.; El-Afify, D. Effects of alpha lipoic acid as a supplement in obese children and adolescents. Cytokine 2020, 130, 155084. [CrossRef]

90. Huerta, M.G.; Roemmich, J.N.; Kington, M.L.; Bovbjerg, M.L.; Weltman, A.; Holmes, V.F.; Patrie, J.T.; Rogol, A.D.; Nadler, J.L. Magnesium Deficiency Is Associated with Insulin Resistance in Obese Children. Diabetes Care 2005, 28, 1175-1181. [CrossRef]

91. Balk, E.; Tatsioni, A.; Lichtenstein, A.; Lau, J.; Pittas, A. Effect of Chromium Supplementation on Glucose Metabolism and Lipids. Diabetes Care 2007, 30, 2154-2163. [CrossRef]

92. Fernández-Cao, J.C.; Medina, M.W.; Moran, V.H.; Arija, V.; Doepking, C.; Serra-Majem, L.; Lowe, N.M. Zinc Intake and Status and Risk of Type 2 Diabetes Mellitus: A Systematic Review and Meta-Analysis. Nutrients 2019, 11, 1027. [CrossRef]

93. Saleem, F.; Rizvi, S.W. New Therapeutic Approaches in Obesity and Metabolic Syndrome Associated with Polycystic Ovary Syndrome. Cureus 2017, 9, 1-11. [CrossRef]

94. Liang, Y.; Xu, X.; Yin, M.; Zhang, Y.; Huang, L.; Chen, R.; Ni, J. Effects of berberine on blood glucose in patients with type 2 diabetes mellitus: A systematic literature review and a meta-analysis. Endocr. J. 2019, 66, 51-63. [CrossRef]

95. Gui, Q.-F.; Xu, Z.-R.; Xu, K.-Y.; Yang, Y.-M. The Efficacy of Ginseng-Related Therapies in Type 2 Diabetes Mellitus. Medicine 2016, 95, e2584. [CrossRef] [PubMed]

96. Jebeile, H.; Gow, M.L.; Baur, L.A.; Garnett, S.P.; Paxton, S.J.; Lister, N.B. Association of Pediatric Obesity Treatment, Including a Dietary Component, with Change in Depression and Anxiety. JAMA Pediatr. 2019, 173, e192841. [CrossRef] [PubMed]

(C) 2020 by the authors. Licensee MDPI, Basel, Switzerland. This article is an open access article distributed under the terms and conditions of the Creative Commons Attribution (CC BY) license (http://creativecommons.org/licenses/by/4.0/). 